
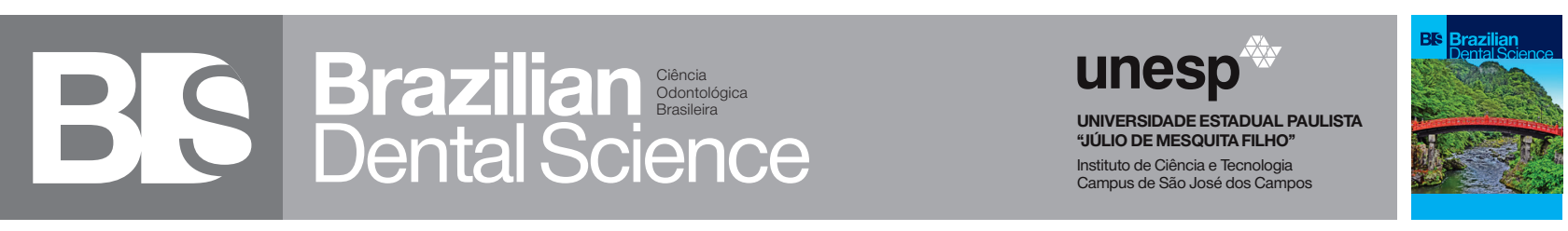

\title{
Influence of indirect reinforcements on the flexural strength of a thermally activated acrylic resin used for complete dentures
}

Influência de reforços indiretos na resistência a flexão de uma resina acrílica ativada térmicamente utilizada na confecção de próteses totais

Jean Soares MIRANDA ${ }^{1}$, Caroline Cotes MARINHO ${ }^{2}$, Vanessa Cruz MACEDO ${ }^{1}$, Aline Serrado de Pinho BARCELLOS ${ }^{1}$, Thaís Cachuté PARADELLA $^{1}$, Tarcísio José Arruda PAES JR ${ }^{1}$, Estevão Tomomitsu KIMPARA ${ }^{1}$

1 - São Paulo State University (Unesp) - Institute of Science and Technology - São José dos Campos - Department of Dental Materials and Prosthodontics - SP - Brazil.

2 - Universidade Brasil - São Paulo - SP - Brazil.

\section{ABSTRACT}

Objective: This research aimed to verify the performance of thermally activated acrylic resin (TAAR) combined with a mix of glass and aramid fibers and/or composite resin of indirect use by a tree point bending test. Material and Methods: Ten samples, with $65 \times 10 \times 2.5 \mathrm{~mm}$, were prepared for each group $(n=10)$ : $C O$, control of only TAAR; $C R$, in which an $60 \mathrm{~mm}$ indirect composite resin was polymerized together with the acrylic resin during the thermo-polymerization cycle; SS, in which ceramic glass mixed with aramid fibers cut $60 \mathrm{~mm}$ in length were incorporated into the samples; and $\mathrm{SC}$, in which the same fibers were incorporated with addiction of the indirect composite resin. A threepoint flexural strength test was performed with a universal testing machine with a load of $50 \mathrm{KgF}$ at a speed of $5 \mathrm{~mm} / \mathrm{min}$ in the center of the samples supported by a suitable device. The reinforced face was placed to the tensile side. The statistical oneway ANOVA and Tukey tests were made with a significance level of 95\%. Results: The mean value for the CO was $60,27 \pm 24,18 \mathrm{MPa}$, for CR it was $38,39 \pm 12,75 \mathrm{MPa}$, for SS it was $79,97 \pm 12,75 \mathrm{Mpa}$

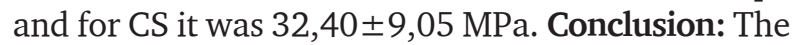
use of glass and aramid fibers at the base of a TAAR increased the three-point flexural strength, however when indirect composite resin was incorporated, a significant drop of this mechanical property was observed.

\section{KEYWORDS}

Acrylic resin; Complete denture; Composite resin.

\section{RESUMO}

Objetivo: Esta pesquisa teve como objetivo verificar o desempenho de uma resina acrílica ativada termicamente (RAAT) combinada com uma mistura de fibras de vidro e aramida e / ou resina composta de uso indireto por um teste de flexão de três pontos. Material e Métodos: Foram preparadas dez amostras, com $65 \times 10 \times 2,5 \mathrm{~mm}$, para cada grupo $(\mathrm{n}=10)$ : $\mathrm{CO}$, controle com apenas RAAT; CR, em que uma resina composta indireta de $60 \mathrm{~mm}$ com polimerizada em conjunto com a resina acrílica durante o ciclo de termopolimerização; SS, em que o vidro cerâmico misturado com fibras de aramida cortadas com $60 \mathrm{~mm}$ de comprimento foi incorporado nas amostras; e SC, nas quais as mesmas fibras foram incorporadas em conjunto com a resina composta indireta. $\mathrm{O}$ teste de resistência à flexão de três pontos foi realizado em uma máquina de teste universal com uma carga de $50 \mathrm{KgF}$ a uma velocidade de $5 \mathrm{~mm} / \mathrm{min}$ no centro das amostras suportadas por um dispositivo adequado. A face reforçado foi colocado no lado da tração. Os testes estatísticos one-way ANOVA e Tukey foram feitos com um nível de significância de 95\%. Resultados: O valor para o CO foi de 60,27 $\pm 24,18$ $\mathrm{MPa}$, para CR foi de $38,39 \pm 12,75 \mathrm{MPa}$, para SS foi de $79,97 \pm 12,75 \mathrm{Mpa}$ e para CS foi de 32, $40 \pm$ 9,05 MPa. Conclusão: o uso de fibras de vidro e aramida na base de uma RAAT aumentou a resistência à flexão de três pontos, no entanto, quando a resina composta indireta foi incorporada, observou-se uma queda significativa dessa propriedade mecânica.

\section{PALAVRAS-CHAVE}

Resina acrílica; Prótese total; Resina composta. 


\section{INTRODUCTION}

$\mathrm{T}$ hermally activated acrylic resin (TAAR), composed by polymethyl methacrylate, is the main material used in edentulous patients rehabilitation. Its use is justified not only for the simplicity of the technique, but also good resistance, durability, biocompatibility, cost-benefit ratio, dimensional and chemical stability. However, it still does not fulfill all the necessary requirements of a rehabilitation material [1-5]. Complete dentures execution with TAAR are done at the cost of clinical and laboratory procedures [1-3].

However, in cases of implant installation to retain and/or give support for complete dentures [6], TAAR present precarious mechanical properties and can frequently fracture [1-3,5,7-10]. This can occur as a result of occlusal disharmony, overloading, fatigue and impact caused by accidents [11-12]. Specially during the osseointegration phase of a protocol type prosthesis, which usually presents cantilever [13], provisional prosthesis made entirely of TAAR may be used over the implants [6]. Thus, the contraindication for the patient is the reduced longevity of such prosthesis.

Therefore, for mucus or implant supported complete dentures, there is the need for TAAR reinforcement, which could result in better mechanical performance, mainly in terms of fracture resistance, allowing greater longevity for these rehabilitations $[1,4,8-9,12]$.

Initially the use of metallic alloys as reinforcement was made in the form of molten metal or stainless-steel wires [14-15]. Although these metallic reinforcements showed a good performance regarding the mechanical aspect [16-18], they presented big interfacial stress and aesthetic disadvantages $[3,11]$. Alternatively, various reinforcing fibers, such as glass $[13,19$ 20], aramid, carbon and polyethylene are commercially available [18-20]. Carbon fibers were useful in strengthening the polymers process but they are not used due to the easy lateral fibers spreading during the processing phase and their low aesthetic quality [3,21], which is also the main disadvantage of aramid fibers [3]. Contrary, silanized glass fibers show better adhesion to the polymeric matrix and superior aesthetics when correctly inserted in the base of complete dentures [3,21].

Polymers are cured by the polymerization reaction and one of the consequences of this reaction is the contraction that occurs at different intensities regarding different types of resins. Considering a possible improvement in the compatibility of silanized glass fibers with the composite resin and considering the difference in the contraction degree of the composite resin compared to the acrylic one, it was supposed the creation of tensions that could improve the final resistance of this aggregation [22].

Considering this, this research aimed to verify the flexural strength of TAAR reinforced with different fibers and composite resin. The null hypothesis tested was that there would be no difference in flexural strength between the control group, without reinforcement, and the different experimental groups, reinforced either with composite resin and/or aramid and glass fibers.

\section{MATERIAL \& METHODS}

\section{Preparation of the samples:}

Three stainless steel patterns with dimensions of $67 \times 12.6 \times 2.55 \mathrm{~mm}$ were used as standard to make a silicone matrix in flasks. Initially, the flasks were filled with type III gypsum (Polident, Agudos, SP, Brazil) in the proportion specified by the manufacturer's instructions (Figure 1).

After the separating agent dried, a laboratory silicone (Rodhorsil, Bluestar Silicones, France) was used around the three standards with a $20 \mathrm{ml}$ syringe, leaving only one side of the patterns without covering. After 30 minutes (silicone polymerization time), the counter part of the flask was positioned and 
filled with type III gypsum in small portions, using a vibrator. After the flasks were properly prepared, they were pressed for 1 hour. After the flasks re-opening, the stainless steel standards were removed and a thin layer of the gypsum surface separation agent was re-applied and the same process was performed with smaller additional metal dies to standardize the space for the reinforcement.

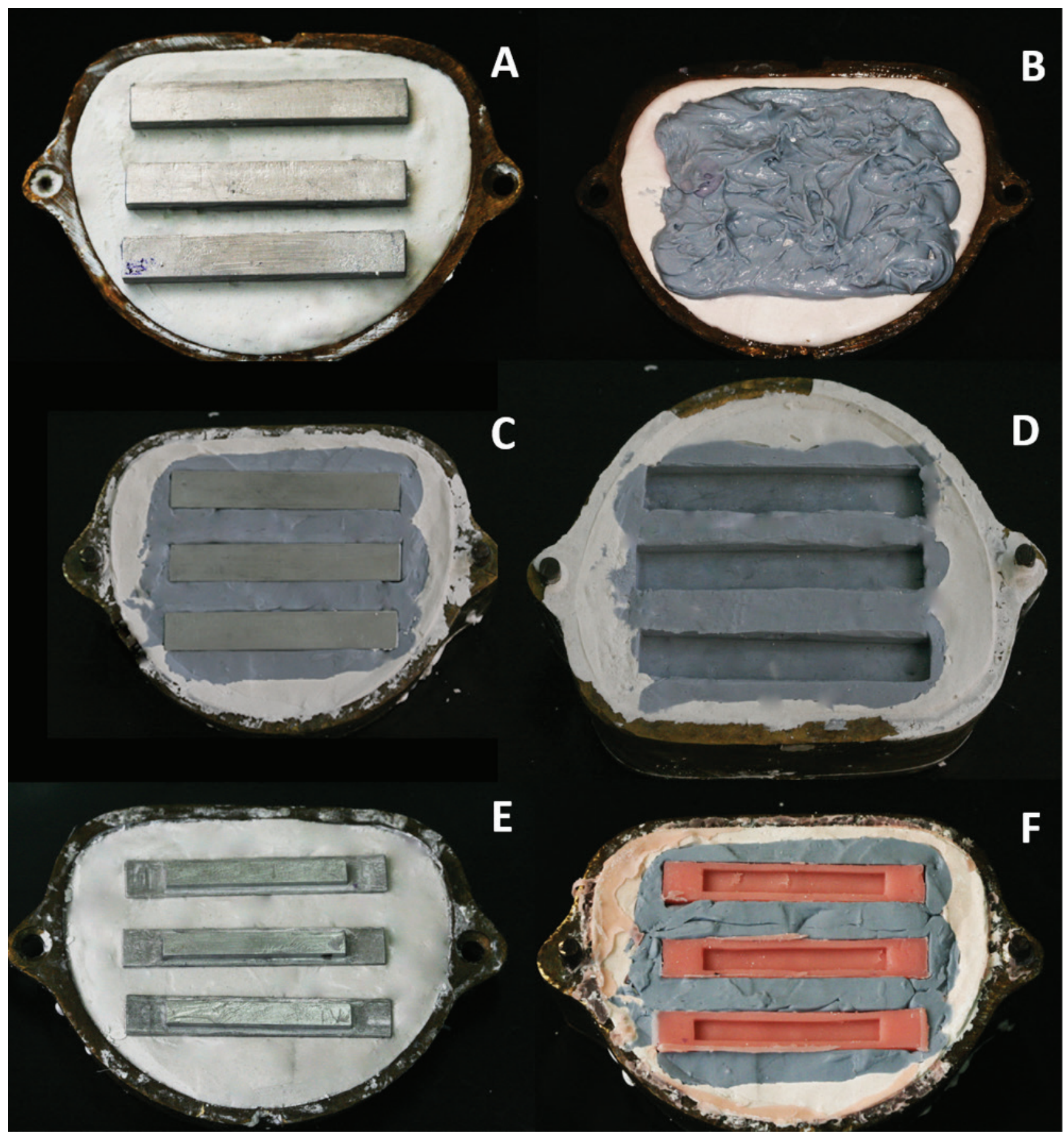

Figure 1 - A) insertion of the patterns on the gypsum with a 10mm space between them; B) wall construction in condensation silicone (Vipisil; VIPI, Pirassununga, São Paulo, Brazil); C) flasks prior to removal of the metallic pattern; D) flasks after removal of the metallic pattern; E) additional metal spacer pattern to standardize the reinforcement space; F) final matrix obtained for the samples. 
After that, ten samples were prepared for each group $(\mathrm{n}=10)$ : $\mathrm{CO}$, control TAAR (Lucitone 550, Dentsply Sirona, São Paulo, SP, Brazil); CR, in which an indirect composite resin (SR Chromasit, Ivoclar Vivadent, Schaan, Liechtenstein) was prepared with $60 \mathrm{~mm}$ in a Centrix syringe and polymerized together with the acrylic resin during the thermopolymerization cycle (Figure 2); SS, in which ceramic glass mixed with aramid fibers (Superfiber, Superdont, Rio de Janeiro, RJ, Brazil) cut $60 \mathrm{~mm}$ in length were incorporated into the samples; and SC, in which the same fibers were incorporated to the samples with addition of CR (Table 1 ).

Table 1 - Groups, reinforcements types and materials used to make the samples

\begin{tabular}{|ccc|}
\hline GRUPS & REINFORCEMENTS TYPES & MATERIALS \\
\hline CO & None & TAAR \\
\hline CR & Indirect composite resin & TAAR + CR \\
\hline SS & Aramid and glass fibers & TAAR + fibers \\
\hline SC & $\begin{array}{c}\text { Indirect resin, aramid and glass } \\
\text { fibers }\end{array}$ & TAAR + CR + fibers \\
\hline
\end{tabular}

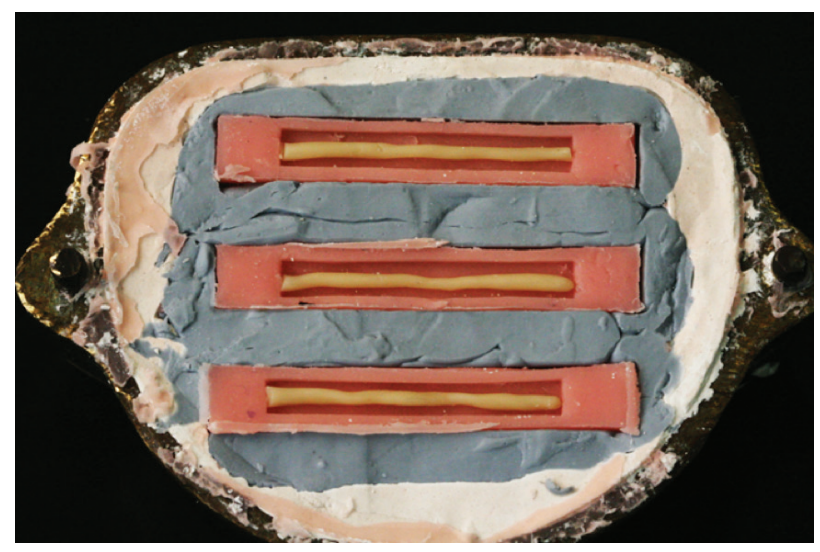

Figure 2 - Insertion of fibers coated with composite resin in the lower area of the matrix which was filled with TAAR.

TAAR was manipulated as recommended by the manufacturer. The flasks were slowly and gradually pressed in a hydraulic press until establishing $1000 \mathrm{Kgf}$, and then maintained for 30 minutes. After the pressing time, the flasks were transferred to an individual press and brought to the polymerization process. The polymerization process was undertaken using a short cycle, as recommended by the manufacturer; the flasks were positioned in cool water and brought to $100^{\circ} \mathrm{C}$, maintaining for 45 minutes at that temperature. Once the process finished, a two-hour period was waited for cooling the flasks at room temperature.

The final dimensions of the samples were $65 \mathrm{~mm} \times 10 \mathrm{~mm} \times 2.5 \mathrm{~mm}$ [23], using two stainless steel devices that served as guides to match the length, width and thickness of the specimens. Specimens were wet grounded to the final dimensions using sandpaper in respective granulation of 180,320 and 600 . After finishing, specimens were stored in a recipient with distilled water inside a kiln at $37^{\circ} \mathrm{C}$ for $48 \pm 2$ hours.

\section{Three-point bending test}

A three-point flexural strength test was performed using a universal testing machine (EMIC, São José dos Pinhais, Paraná, Brazil) with a load of $50 \mathrm{kgf}$ at a cross-head speed of 5 $\mathrm{mm} / \mathrm{min}$ at the center of the samples supported by a suitable device. The reinforced face was placed to the tensile side (Figure 3).

The fracture load was recorded in Newtons (N) and the flexural strenght (FS) was calculated in $\mathrm{MPa}$ with the following equation $\mathrm{FS}=3 \mathrm{FD} / 2 \mathrm{LH} 2$, where $\mathrm{F}$ is the maximum load supported by the specimen before its fail, which was determined in Newton $(\mathrm{N})$; D is the span distance $(50 \mathrm{~mm})$; $\mathrm{L}$ is the width of the specimens $(10 \mathrm{~mm}) ; \mathrm{H}$ is the thickness of the specimens $(2.5 \mathrm{~mm})$. The dimensions were checked with the aid of a digital pachymeter (Mitutoyo, Suzano, São Paulo, Brazil).

Data were tabulated and submitted to the normality test, which indicated the possibility of performing a one-way ANOVA and Tukey tests with a significance level of 95\%. 


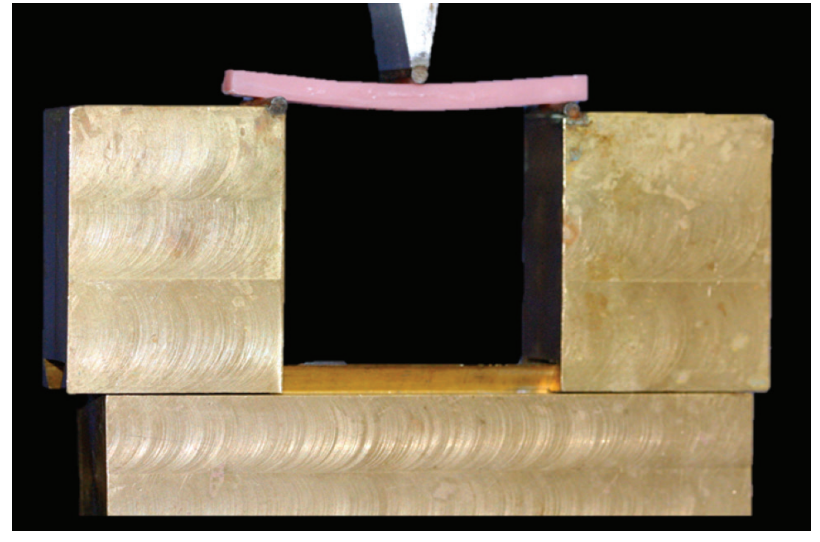

Figure 3 - Sample position during execution of the three-point bending test.

\section{RESULTS}

Through the ANOVA statistical test, it was possible to verify that there was a significant statistical difference between the groups ( $\mathrm{p}=$ 0.01). Tukey test indicated that the application of the indirect composite resin reduced the flexural strength of the samples, while the use of glass and aramid fibers was beneficial to the resistance. Therefore, the group that presented the greatest flexural strength was SS, followed by $\mathrm{CO}, \mathrm{CH}$ and CS, respectively (Table 2 ).

Table 2 - Three-point flexural strength data of the control and experimental groups

\begin{tabular}{|cc|}
\hline GRUPS & MEAN \pm STANDARD DEVIATION $(\mathrm{MPa})$ \\
\hline CO & $60.27 \pm 24.18 \mathrm{~B}$ \\
\hline CR & $38.39 \pm 12.75 \mathrm{~A}$ \\
\hline SS & $79.97 \pm 12.75 \mathrm{C}$ \\
\hline CS & $32.40 \pm 9.05 \mathrm{~A}$ \\
\hline
\end{tabular}

\section{DISCUSSION}

In this research, glass and aramid fibers and/or indirect composite resin were added as an attempt to reinforce TAAR. To evaluate these treatments, a three-point bending test was performed. This test is the most used to evaluate acrylic resin resistance [1-3,7,10-12,14,21,22], because the three-point test simulates a bending failure caused by deformation of the base of the complete prosthesis $[3,12,14]$, being preferable to torsion, compression or shear tests [7]. Trying to simulate the conditions of a complete prosthesis, the thickness of the experimental bars was $2.5 \mathrm{~mm}$, which is the dimension also used in others researches [7,11-12] and it is close to the one clinically used in a prosthesis base.

Insertion sites of the reinforcement material in the TAAR can be in the upper face of the prosthesis base [1], in the medium [1,10] or in the lower region [1,9]. Agha, Flinton and Vaidyanathan [1] evaluated the strength influence of the glass fiber reinforcement on TAAR bars and reported that the placement of the fibers closer to the lower region was more favorable to this material resistance, fact that guided the preparation of the specimens in our research. The beneficial effects of fiber reinforcement on the tensile side [9], face subjected to increased stress, can be attributed to the ability of the fiber to absorb more energy by stretching of the fibers, before the occurrence of the fracture. As a result, the stress required for the initiation of crack growth and its subsequent propagation is postponed until a greater stress is required or the fracture to be properly initiated [1].

Analyzing the obtained results, the null hypothesis was rejected, since all the experimental groups obtained different results when compared to the control group. In groups which indirect resin was inserted, a decrease in resistance was found. Although da Silva et al. [22] reported the opposite, this decrease in resistance values can be justified by the fact that the elastic modulus of the composite resin is higher than the acrylic resin [24,25], not allowing the bars with this composite to undergo so much plastic deformation compared with pure acrylics or fibers reinforced bars and fractured with a lower load.

Another factor to be considered is that the composite resin used in this research did not promote an efficient penetration into the surface of the acrylic resin, resulting in a structure with faults, in which the fractures could be originated 
easily. Some studies used a more flowing material such as a fluid composite resin, for example, after an application of the methyl methacrylate monomer, showing better results between an acrylic resin and a composite resin [26,27].

However, the insertion of glass and aramid fibers without the inclusion of composite resin was beneficial. This result is supported by previous papers [1-3,5,9,12,21]. Several researches obtained a significantly higher TAAR resistance when they were reinforced with some type of fiber, compared with specimens without any reinforcement $[1,3,5,9,12,21]$, reinforced with nylon fibers [2] or even metallic ones [7]. Therefore, glass and aramid fibers can be considered suitable for dental prosthesis [2,9], and even have longitudinal studies as proof [9].

By an aesthetic perspective, glass fibers are mostly used in anterior region [12], however, the combination of different fibers is proven beneficial, which is due in part to the total volume of fibers [3]. Another factor that, according to YU et al. [3], also affects the mechanical properties of the reinforced TAAR is the diameter of the fibers. When they increase, a higher resistance of the sample is generated [3].

This research was an in vitro study and its results cannot be fully compared to clinical situations due to biological variables. However, important criteria, such as sample thickness and type of test performed, were incorporated into the design during the preparation of the samples and execution of the mechanical test so that the conclusions of the study could be considered valid from a clinical perspective.

\section{CONCLUSION}

The use of glass and aramid fibers at the base of a thermally activated acrylic resin increased the three-point flexural strength, however when indirect composite resin was incorporated into the specimens a significant drop of this mechanical property was observed.

\section{REFERENCES}

1. Agha H,Flinton R, Vaidyanathan T.Optimization of Fracture Resistance and Stiffness of Heat-Polymerized High Impact Acrylic Resin with Localized E-Glass fiber FORCE Reinforcement at Different Stress Points. JProsthodont. 2016 Dec;25(8):647-655. doi: 10.1111/jopr.12477. Epub 2016 Mar 16.

2. LadhaK, Shah D. An In-Vitro Evaluation of the Flexural Strength of HeatPolymerized Poly (Methyl Methacrylate) Denture Resin Reinforced with Fibers. J Indian Prosthodont Soc. 2011Dec;11(4):215-20. doi: 10.1007/s13191-011-0086-5. Epub2011Jul 14.

3. YuSH, Lee Y,Oh S, Cho HW, Oda Y,Bae JM. Reinforcing effects of diferente fibers on denture base resin based on the fiber type, concentration, and combination. Dent Mater J. 2012;31(6):1039-46.

4. Jagger DC, Harrison A, Jandt KD. Review The reinforcement of dentures. J Oral Rehabil. 1999 Mar;26(3):185-94.

5. Im SM, Huh YH, Cho LR, Park CJ. Comparison of the fracture resistances of glass fiber mesh- and metal mesh-reinforced maxillary complete denture under dynamic fatigue loading. J Adv Prosthodont. 2017 Feb;9(1):22-30. doi: 10.4047/jap.2017.91.22. Epub 2017 Feb 7.

6. Gonçalves FCP,Amaral M, Borges ALS, Gonçalves LFM, Paes-Junior TJA. Fracture load of complete-arch implant-supported prostheses reinforced with nylon-silica mesh: An in vitro study. J Prosthet Dent. 2018 Apr;119(4):606-610. doi: 10.1016/.jprosdent2017.05.018. Epub 2017 Jul 11.

7. Heidari B, Firouz F, Izadi A, Ahmadvand S, Radan P.Flexural Strength of Cold and HeatCure Acrylic Resins Reinforced with Different Materials. J Dent (Tehran). 2015 May;12(5):316-23.

8. Bertassoni LE, Marshall GW, de Souza EM, Rached RN. Effect of pre-and postpolymerizationon flexural strength and elasticmodulus of impregnated, fiberreinforceddenture base acrylic resins. J Prosthet Dent. 2008 Dec;100(6):449-57.doi: 10.1016/S0022-3913(08)60263-2.

9. Goguță LM, Bratu D, Jivănescu A, Erimescu R, Mărcăuțeanu C. Glass fibre reinforced acrylic resin complete dentures: a5-year clinical study. Gerodontology.2012 Mar;29(1):64-9. doi: 10.111//1.1741-2358.2010.00385.x. Epub 2011Jun22.

10. Yoshida K, Takahashi Y,Sasaki H, Hamanakal,Kawaguchi T. Flexural strengths of reinforced denture base resins subjected to long-term water immersion. Acta Biomater Odontol Scand. 2016 Jan 26;2(1):20-24. doi: 10.3109/23337931.2015.1135745. eCollection2016 Dec.

11. Fonseca RB, Kasuya AVB, Favarão IN, Naves LZ, Hoeppner MG. The Influence of Polymerization Type and Reinforcement Method on Flexural Strength of Acrylic Resin. ScientificWorldJournal. 2015;2015:919142 doi: 10.1155/2015/919142. Epub 2015 Mar 23.

12. Anasane N, Ahirrao Y,Chitnis D, Meshram S. The effect of joint surface contours and glass fiber reinforcement on the transverse strength of repaired acrylic resin: An in vitro study. Dent Res J (Isfahan). 2013 Mar;10(2):214-9.

13. Tacir IH,Kama JD, Zortuk M, EskimezS. Flexural properties of glass fibre reinforced acrylic resin polymers. Aust Dent J. 2006 Mar;51(1):52-6.

14. LiBB, Xu JB, Cui HY, Lin Y,Di P. In vitro evaluation of the flexural properties of All-on-Four provisional fixed denture base resin partially reinforced with fibers. Dent Mater J. 2016;35(2):264-9. doi:10.4012/dmj.2015-243.

15. Dalkiz M, Arslan M, Tuncdemir AR, Bilgin ML, Aykul H. Effect of different palatal vault shapes on the dimensional stability of glass fiber-reinforced heatpolymerized acrylic resin denture base material. Eur J Dent. 2012 Jan;6(1):70-8.

16. Gonda T, Ikebe K, Dong J, Nokubi T.Effect of reinforcement on overdenture strain. JDentRes. 2007 Jul;86(7):667-71. 
17. Minami H, Suzuki S, Kurashige H, Minesaki Y, Tanaka T. Flexural strengths of denture base resin repaired with autopolymerizing resin and reinforcements after thermocycle stressing.JProsthodont. 2005 Mar;14(1):12-8.

18. Fahmy NZ, Sharawi A. Effect of two methods of reinforcement on the fracture strength of interim fixed partial dentures. J Prosthodont. 2009 Aug;18(6):51220. doi: 10.1111//.1532-849X.2009.00468.x. Epub 2009 Apr 21.

19. Narva KK, Lassila LV, VallittuPK. The static strength and modulus of fiber reinforced denture base polymer.Dent Mater. 2005 May;21(5):421-8.

20. Doğan OM, Bolayir G, Keskin S, Doğan A, Bek B. The evaluation of some flexural properties of a denture base resin reinforced with various aesthetic fibers. J Mater Sci Mater Med. 2008 Jun;19(6):2343-9. Epub 2007 Dec 23.

21. Natarajan P, Thulasingam C. The Effect of Glass and Polyethylene Fiber Reinforcement on Flexural Strength of Provisional Restorative Resins: An In Vitro Study. J Indian Prosthodont Soc. 2013 Dec;13(4):421-7. doi: 10.1007/s13191012-0148-3. Epub 2012 Jul 14.

22. da Silva LH, de Castro HL, Tango RN, de Arruda Paes Júnior TJ, KimparaET. Evaluation of flexural resistance of a denture base acrylic resin reinforced with glass fiber and with composite resin. Eur J Prosthodont Restor Dent.2010 Sep;18(3):107-10.
23. American Dental Association. Specification $n 12$ for denture base polymers. Councils on Dental Materials and Devices, Reports of Councils and Bureaus. J AmDent Assoc 1975;90:39-49.

24. Borges ALS, Borges AB, Barcellos DC, Saavedra GSFA, Paes Junior TJA, Rode SM. Assessment of flexural strength and elastic modulus of different indirect composite resins. RPG - Rev Pós-Grad. 2012 Jun;19(2):50-6.

25. VieiraPR, Vieira J,Carvalho EML. Análise das propriedades de compósitos poliméricos reforçados com fibra de vidro. Engevista. 2016 Dec;18(2):363-74.

26. PapazoglouE, Vasilas Al. Shear bond strengths for composite and autopolymerized acrylic resins bonded to acrylic resin denture teeth.J Prosthet Dent. 1999 Nov;82(5):573-8.

27. Vergani CE, Machado AL, Giampaolo ET, Pavarina AC. Effect of surface treatments on the bond strength between composite resin and acrylic resin denture teeth. Int JProsthodont. 2000 Sep-0ct;13(5):383-6.

\section{Estevão Tomomitsu Kimpara}

\section{(Corresponding address)}

Department of Dental Materials and Prosthodontics, Institute of Science and Technology, Paulista State University (UNESP)

Avenida Engenheiro Francisco José Longo, 555, Jardim São Dimas, São José dos Campos/SP, Brasil

(12) 39479032 